International Journal of Environment, Agriculture and Biotechnology
Vol-6, Issue-6; Nov-Dec, 2021
J Journal Home Page Available: https://ijeab.com/
Journal DOI: $10.22161 /$ ijeab

\title{
Artificial Insemination Rate and Income of Farmers in Padang Pariaman District
}

\author{
Eriya Oktanova ${ }^{1}$, Jaswandi $^{2}$, Arfa'i $^{2}$, Syintia Dwi Agustina ${ }^{3}$
}

${ }^{1}$ Magister Student at Graduate Program of Faculty of Animals Science at Universitas Andalas, Kampus Limau Manis, Padang, Indonesia, 25163

${ }^{2}$ Lecturer at Under Graduate of Faculty of Animal Science, Universitas Andalas, and Graduate Program at Universitas Andalas, Kampus Limau Manis, Padang, Indonesia, 25163

${ }^{3}$ Lecturer at Under Graduate of Faculty of Agriculture, Universitas Musi Rawas, Lubuklinggau City, Sumatera Selatan, Indonesia, 31625

Received: 15 Sep 2021; Received in revised form: 22 Oct 2021; Accepted: 02 Nov 2021; Available online: 12 Nov 2021

(C)2021 The Author(s). Published by Infogain Publication. This is an open access article under the CC BY license

(https://creativecommons.org/licenses/by/4.0/).

\begin{abstract}
This study aims to determine the success rate of artificial insemination in beef cattle and the implications of artificial insemination in beef cattle on the income of farmers in Padang Pariaman Regency, West Sumatra. This study uses a survey method by interviewing 93 farmers and observing the cattle kept by the community in the research location. Sample selection was done by the accidental sampling method. The research data was obtained from artificial insemination reporting data in Padang Pariaman Regency which was taken as many as 957 acceptors, with 520 heads of Coastal cattle, 166 head of Bali cattle, 193 Simmental Peranakan cattle, 11 Brahman cattle, 35 PO cattle, and Limousin breed 32 tails. The variables observed were the characteristics of the breeder (age, education level, main occupation, experience in raising livestock, and the number of livestock kept). Inseminator Characteristics (age, education level, years of service, and activity of officers in the field), IB services, maintenance techniques (cattle that were maintained, feed given, maintenance management), IB success based on livestock reproduction ( $\mathrm{S} / \mathrm{C}$, Conception rate, and Calving rate) and IB implications for farmer's income (revenues, costs incurred/profits). Based on the results of research on the success rate of Artificial Insemination in Beef Cattle in Padang Pariaman Regency, it can be concluded that Service per Conception $(S / C)$ is 1.36 times, Conception Rate $(C R)$ is $70.32 \%$, Calving Rate (CVR) $45.98 \%$. The implication of artificial insemination is that based on pregnancy and birth of livestock and the profits obtained from livestock that are born so that there is an added value and is reduced by the cost of feed, cage equipment, drug costs affect the income of farmers so that the net profits obtained by farmers are obtained.
\end{abstract}

Keywords- Artificial Insemination, Calving Rate (CVR), Conception Rate (CR), IB Implications, Service per Conception (S/C).

\section{INTRODUCTION}

The development of the livestock sub-sector in Indonesia needs to be increased, considering that the demand for livestock products tends to increase from year to year. On the other hand, the fulfillment of animal protein needs is still low, especially from ruminant meat, namely $5.5 \mathrm{~g} /$ capita/day or $2.02 \mathrm{~kg} /$ capita/year.

The increasing demand for beef is not matched by the population of beef cattle in Indonesia. The low population of beef cattle in Indonesia is due to the lack of successful livestock development in Indonesia (Talib et al. 2007). Therefore, it is necessary to increase the production and population of beef cattle.

The way to improve or increase beef cattle through seeds is by artificial insemination (Sudarmono and Sugeng, 2016). At the end of 2016, the government had launched the Upsus Siwab program (a special effort to accelerate the increase in the population of pregnant cows and buffalo) and now it has changed its name to Sikomandan (buffalo cattle, the mainstay of domestic 
commodities). The government claims the program can increase the population as well as improve the welfare of farmers.

Padang Pariaman Regency is one of the areas in West Sumatra that has intensively implemented an artificial insemination program since 1985. To optimize livestock reproduction, the government through the Sikomandan program has the principle of accelerating adult cows ready to become pregnant by conducting artificial insemination programs, pregnancy checks, and birth reporting. The Sikomandan program can be realized even better according to the birth targets set by each City/Regency. Pregnancy and birth are one of the main factors for the success of the Sikomandan program.

The total number of cattle in Padang Pariaman Regency in 2020 was recorded at 43,629 heads, but based on reports in the last 3 years there is a tendency to decrease the number of births. Where in 2017 the target for the birth of beef cattle was 4,717 heads and the realization exceeded the target of 5,908 heads. In 2018 the birth target increased to 5,244 tails with the realization of 5,900 birds. But in 2020 the target for beef cattle births decreased from 2019 to 5,076 heads with the realization decreasing from 2019 as many as 5,181 heads. It is not known for certain what causes births in Padang Pariaman Regency to decline in 2020 .

According to the Ministry of Agriculture (2019), there are several problems in the implementation of artificial insemination, namely the knowledge of breeders is still low on AI, delays in the distribution of AI facilities and infrastructure, reproductive management, especially in semi-intensive and extensive areas, limited access to acceptors due to the difficult topography of the area and many conditions. livestock that is not good because of limited feed and reproductive disorders. Therefore, to optimize the results of successful artificial insemination through the Sikomandan program, these problems must be a serious concern to be resolved. The purpose of this study was to determine the success rate of artificial insemination based on reproductive performance in Padang Pariaman Regency and the implications of artificial insemination in beef cattle on the income of farmers in Padang Pariaman Regency.

\section{MATERIAL AND METHOD}

\subsection{Materials Research}

The materials used in this study were 520 coastal cattle, 166 Bali cattle, 193 Simental crossbreeds, 11 Brahman cattle, 35 PO cattle, and 32 Limousin crossbreed cattle which were IB acceptors and were recorded in Isikhnas.

\subsection{Research Implementation}

This study used a survey method with interviews with farmers and made observations of cattle kept by the community in the research location. The research samples taken are:

1. Data on the results of reporting on artificial insemination in beef cattle in Kabupaten Padang Pariaman were taken randomly. The data taken is the highest data on the implementation of artificial insemination in beef cattle in Padang Pariaman Regency, namely in June 2020, and data on livestock births from March to May 2021.

2. Farmers who have sold beef cattle resulting from artificial mating or artificial insemination. Determination of farmers who were interviewed as many as 93 farmers, using the accidental sampling method, which is a sampling technique based on chance, where anyone who coincidentally / incidentally meets the researcher can be used as a sample if it is seen that the person met is suitable as a data source (Sugiyono, 2005).

\subsection{Observed variables}

1. Characteristics of the breeder (age, education level, main occupation, experience in raising livestock, and the number of livestock kept).

2. Characteristics of Inseminators (age, education level, years of service, and activeness of officers in the field).

3. Maintenance techniques (seeds are maintained, feed given, maintenance management).

4. IB success based on livestock reproduction (S/C, Conception rate, Calving interval, Calving rate)

a. Service per conception $(\mathrm{S} / \mathrm{C})$

Service per conception $(\mathrm{S} / \mathrm{C})$ is the number of inseminations needed for a pregnancy to occur. Data were obtained from inseminator records.

\section{b. Conception Rate}

The pregnancy rate or conception rate is the percentage of women who are pregnant in the first IB (Hafez, 2000).

\section{c. Calving Rate}

The calving rate is the percentage of the number of females giving birth to live calves of the total number of mated females.

5. Implications of IB on farmer's income (revenues, costs incurred) 
The analysis used in this research is by looking at the comparison between revenue and total cost or $\mathrm{R} / \mathrm{C}$ ratio so that from the comparison results can be seen the level of success and efficiency of farming. There are three possible conclusions from the analysis results from the above formulation, namely as follows:

* Revenue cost ratio $(\mathrm{R} / \mathrm{C})>1$ cattle business is feasible.

* Revenue costs ratio $(\mathrm{R} / \mathrm{C})=1$ cattle business reaches the break-even point, that is, neither gain nor loss.

* Revenue cost ratio $(\mathrm{R} / \mathrm{C})<1$ then cattle farming is not feasible.

\subsection{Data Analysis}

\section{a. Service/Conception (S/C)}

$\mathrm{SC}=\frac{\text { number of inseminations that result in pregnancy }}{\text { Number of pregnant cows }}$

\section{b. Conception Rate (CR)}

$\mathrm{CR}=\frac{\text { the number of pregnancy results of the } 1 \text { st IB }}{\text { number of acceptors }} \times 100 \%$

\section{c. Calving Rate}

Calving Rate $=\frac{\text { number of births }}{\text { number of acceptors }} \times 100 \%$

\section{d. Income}

$$
\pi=\mathrm{TR}-\mathrm{TC}
$$

Information:

$\pi=$ net income / profit

$\mathrm{TR}=$ total gross income/receipt

$\mathrm{TC}=$ total cost of production

\section{RESULT AND DISCUSSION}

\subsection{Characteristics of Breeders}

Characteristics of breeders are one aspect that is quite important in a livestock business and has an influence on innovation. This is done to determine the identity of the farmers involved in this study. However, a farmer cannot be separated from the factors that influence his business in raising livestock, including age, gender, education level, main occupation, number of livestock kept, and experience of raising livestock as shown in Table 1.

Table 1. Characteristics of Beef Cattle Breeders in Kabupaten Padang Pariaman

\begin{tabular}{llcc}
\hline No. & \multicolumn{1}{c}{ Characteristics } & $\begin{array}{c}\text { Amount } \\
\text { (Person) }\end{array}$ & $\begin{array}{c}\text { Percentage } \\
(\%)\end{array}$ \\
\hline 1. & Breeder's Age & & \\
& $<30$ Years & 4 & 4,30 \\
& 30-50 Years & 51 & 54,84 \\
\hline
\end{tabular}

\begin{tabular}{|c|c|c|c|}
\hline & $>50$ Years & 38 & 40,86 \\
\hline \multirow[t]{6}{*}{2.} & Level of education & & \\
\hline & No school & 4 & 4,30 \\
\hline & SD & 39 & 41,94 \\
\hline & junior high school & 27 & 29,03 \\
\hline & senior High School & 20 & 21,50 \\
\hline & College & 3 & 3,23 \\
\hline \multirow[t]{4}{*}{3.} & The main job & & \\
\hline & Farmer & 67 & 72,04 \\
\hline & Trader/Entrepreneur & 22 & 23,66 \\
\hline & Employees/Retirees & 4 & 4,30 \\
\hline \multirow[t]{4}{*}{4.} & $\begin{array}{l}\text { Number of Cattle } \\
\text { Raised }\end{array}$ & & \\
\hline & $<5$ Tails & 47 & 50,54 \\
\hline & 5-10 Tails & 44 & 47,31 \\
\hline & $>10$ Tails & 2 & 2,15 \\
\hline \multirow[t]{4}{*}{5.} & Farming Experience & & \\
\hline & 1-5 Years & 20 & 21,51 \\
\hline & 6-10 Years & 24 & 25,81 \\
\hline & $>10$ Years & 49 & 52,69 \\
\hline
\end{tabular}

\subsection{Characteristics of Inseminator}

Inseminator characteristics need to be known in addition to the characteristics of breeders because they can support the success of artificial insemination in the Padang Pariaman Regency, which can be seen in Table 2.

Table 2. Characteristics of Inseminators in Padang Pariaman Regency.

\begin{tabular}{llcc} 
No. & \multicolumn{1}{c}{ Characteristics } & $\begin{array}{c}\text { Amount } \\
(\text { Person })\end{array}$ & $\begin{array}{c}\text { Percentage } \\
(\%)\end{array}$ \\
\hline 1. & $\begin{array}{l}\text { Age } \\
\text { 20-60 Years } \\
>60 \text { Years }\end{array}$ & 36 & 100 \\
& - &
\end{tabular}

2. Level of education

Senior High School $\quad 19 \quad 52,78$

Diploma $4 \quad 1 \quad 2,78$

Bachelor Degree $\quad 16 \quad 44,44$

3. Years of service

0-3 Years $\quad 10 \quad 27,784$

4-10 Years $\quad 16 \quad 44,44$




\begin{tabular}{llcc}
\hline & $11-20$ Years & 10 & 27,78 \\
\hline 4. & IB Service & & \\
& Active & 33 & 91,67 \\
& Passive & 3 & 8,33
\end{tabular}

Source: Primary data that has been processed by researchers, 2021.

Based on Table 3 above, the characteristics of the age level of the inseminator officers in Padang Pariaman Regency are classified in the productive category with an average age of 20-60 years, namely 36 officers with a percentage of $100 \%$.

The last education level of the inseminators was high school as much as $52.78 \%$ or 19 people, and D4 as many as 1 person $(2.78 \%)$, and $\mathrm{S} 1$ as many as 16 officers $(44.44 \%)$. This level of education shows that the inseminators in Padang Pariaman Regency have a good level of knowledge, and have sufficient experience with an average working period of 4-10 years, namely $44.44 \%$. This shows that the implementation of IB is expected to run well because it has skilled and experienced inseminators.

In the artificial insemination service system, officers are quite active in serving farmers. Of the 36 officers as many as 33 active officers directly serve farmers to the field with a percentage of $91.67 \%$ and there are also passive officers as many as 3 people with a percentage of $8.33 \%$. This is due to the dual work that is as an inseminator and as a civil servant.

\subsection{Livestock Maintenance Techniques}

The technical maintenance of livestock can be seen from the type of cattle kept, the feed provided, maintenance management, and disease prevention/treatment.

\subsubsection{Types of livestock kept}

The types of beef cattle kept by farmers in the Padang Pariaman Regency area can be presented in Table 3.

Table 3. Types of Seeds Raised by Breeders in Kabupaten Padang Pariaman

\begin{tabular}{llcc}
\hline No & \multicolumn{1}{c}{ Breed Type } & $\begin{array}{c}\text { Amount } \\
\text { (tail) }\end{array}$ & $\begin{array}{c}\text { Percentage } \\
(\%)\end{array}$ \\
\hline 1. & Pesisir cow & 520 & 54.38 \\
2. & Bali Cow & 166 & 17.33 \\
3. & Simmental & 193 & 20.15 \\
& Crossbreed Cow & 11 & 1.15 \\
4. & Brahman Cow & 35 & 3.65 \\
5. & PO cows & 32 & 3.34 \\
\hline
\end{tabular}

\begin{tabular}{lll}
\hline 6. Limousine Breed & & \\
Cow & 957 & 100.00 \\
\hline
\end{tabular}

Source: Primary data that has been processed by researchers, 2021.

\subsubsection{Feed}

Types of feeding include forage, concentrate, and agricultural waste can be seen in Table 4 .

Table 4. Types of Beef Cattle Feeding in Kabupaten Padang Pariaman.

\begin{tabular}{clc}
\hline No & \multicolumn{1}{c}{ Giving } & Percentage $(\%)$ \\
\hline 1. & Forage only & 65,59 \\
2. & Forage and Concentrate & 8,60 \\
& Forage and Agricultural & 21,51 \\
3. & Waste Forage & 4,30 \\
& Concentrate and & \\
4. & Agricultural Waste & \\
\hline
\end{tabular}

100.00

Source: Primary data that has been processed by researchers, 2021.

In Table 4, the provision of forage by breeders in Kabupaten Padang Pariaman is $65.59 \%$. This is because farmers release their cows during the day and additional grass is given once in the afternoon or evening. From the results of interviews with farmers, they consider that the provision of forage is sufficient for the cows they raise and the provision of concentrate only adds to the cost. To produce good productivity, of course, it is necessary to provide good quality feed as well as support for cattle growth.

To spur increased productivity and reproducibility of livestock, it is necessary to support feed capacity both in quality and quantity. Leguminous plants are a type of forage that is prospectively developed because it has high protein content and is available in-situ on farmland. However, its potential has not been utilized by farmers as feed ingredients. The use of this forage as feed for ruminants can partially replace the need for concentrate (Hendri et al., 2010).

In addition, $8.60 \%$ of beef cattle breeders in Padang Pariaman Regency provide feed in the form of forage and concentrates. This breeder understands that it is also necessary to provide additional feed other than forage, usually farmers who provide this concentrate are for fattening cattle for beef cattle traders. The concentrate given is in the form of bran and tofu dregs. For the time of giving in the morning before giving forage, but some 
breeders give concentrate at night. For the provision of agricultural waste given in the form of banana stems, rice straw, and sago.

\subsubsection{Maintenance Management}

The management of beef cattle maintenance in Padang Pariaman Regency can be seen in Table 5.

Table 5. Management of Beef Cattle Maintenance in Padang Pariaman Regency.

\begin{tabular}{llcc}
\hline No & \multicolumn{1}{c}{ Governance } & $\begin{array}{c}\text { Number of } \\
\text { Breeders } \\
\text { (person) }\end{array}$ & $\begin{array}{c}\text { Percentage } \\
(\%)\end{array}$ \\
\hline 1. & $\begin{array}{l}\text { Maintenance } \\
\text { System: }\end{array}$ & 1 & 1,08 \\
& Intensive & 92 & 98,92 \\
& Semi Intensive & - & - \\
Extensive & &
\end{tabular}

2. Cage Building:

$\begin{array}{lcc}\text { Semi permanent } & 2 & 2,15 \\ \text { concrete floor } & 24 & 25,81 \\ \text { concrete floor wood } & 67 & 72,04 \\ \text { Ground floor wood } & & \end{array}$

3. Cleaning the Cage:

Once a week 26

Once a month 67 72,04

Once a year

Source: Primary data that has been processed by researchers, 2021.

In Table 5, the most beef cattle rearing system is maintained with a semi-intensive system with $98.92 \%$. Beef cattle are reared in a semi-intensive system, where the cattle are released during the day to look for food and at night are kept in cages. Livestock are released from 8.00 am to $5.00 \mathrm{pm}$. While the intensive rearing system is $1.08 \%$, namely cattle are kept in cages without being released and full feeding is provided.

Beef cattle that are reared obtain forage in rice fields that are not planted with rice or that have been harvested, plantation areas, bushland, yards or roadsides. During the growing season, some cows are tied up by their owners somewhere to graze so as not to disturb the plants. In addition, farmers make fences in the planting area so as not to be disturbed by livestock that are allowed to roam. Besides getting forage from grazing, some farmers look for grass to give to livestock in the afternoon, especially during the rice planting season (Adrial, 2010). The cowshed building is generally made of wood that surrounds the entire cage ansd has $72.04 \%$ of the ground floor.

\subsection{IB Success Rate Based on Livestock Reproduction}

The success rate of artificial insemination is strongly influenced by four interrelated factors and cannot be separated from one another, namely the selection of acceptor cows, semen quality testing, the accuracy of estrus detection by breeders, and the inseminator skills. In this case, the inseminator and breeder have a very important role in the implementation of $\mathrm{AI}$ as well as the party responsible for the success or failure of the artificial insemination program in the field.

The success rate of the artificial insemination program in this study was also assessed from insemination per conception or Service per Conception (S/C), Conception Rate or conception rate (CR), and Calving Rate or birth rate (CVR).

Table 6. Value of Service per Conception (S/C), Conception Rate (CR), and Calving Rate (CVR) Beef Cattle in Padang Pariaman Regency.

\begin{tabular}{clcc}
\hline No. & Reproductive Value & $n$ & Results \\
\hline 1. & S/C & 957 & 1.36 times \\
2. & CR & 957 & $70.35 \%$ \\
3. & CvR & 957 & $45.98 \%$ \\
\hline
\end{tabular}

Source: Primary data that has been processed by researchers, 2021.

\subsubsection{Value of Service per Conception $(\mathrm{S} / \mathrm{C})$}

Service per Conception is a number that shows the number of marriages until a pregnancy occurs. From the results of research that has been carried out the value of $\mathrm{S} / \mathrm{C}$ on beef cattle in Padang Pariaman Regency is included in the good category. The value of $\mathrm{S} / \mathrm{C}$ obtained is 1.36 times with the number of acceptor cattle as many as 957 heads. The lower the value, the higher the fertility value of the female livestock in the group, conversely the higher the $\mathrm{S} / \mathrm{C}$ value, the lower the fertility value of the female group. The results of this study are almost the same as the results of research by Riyanto, et al (2015) S/C of beef cattle in Mojogedang District, Central Java is 1.33-1.71 times. The results of this study are close to Udin's (2012) statement that the perfect or ideal $S / C$ value is one, which means that the animal is pregnant at one time IB, the optimum value is 1.6 or ranging from 1.4-1.8.

Nuryadi and Wahjuningsih (2011) stated that if the $\mathrm{S} / \mathrm{C}$ is low, then the fertility value of the female cow is higher and if the $\mathrm{S} / \mathrm{C}$ is high, the fertility rate of the female cow is lower. Following the opinion of Nebel (2002) 
which states that tilapia $\mathrm{S} / \mathrm{C}$ is influenced by several factors including female fertility, semen quality, maintenance management, and inseminator skills.

The implementation of IB in Padang Pariaman Regency is carried out by experienced officers who have a permit to carry out Artificial Insemination (SIMI), have expertise in pregnancy inspection (PKB), ATR (Reproductive Technical Assistant), and semen handling. This is following the Decree of the Minister of Agriculture (2012) which states that the technical implementation of $\mathrm{AI}$ in the field requires officers who have special skills that are not easy for everyone to do.

The S/C value of beef cattle in Padang Pariaman Regency is said to be quite good, this situation is supported by most of the knowledge of farmers about signs of lust so that reporting to the inseminator officers is not too late. The S/C value indicates the level of livestock fertility. The greater the value of $\mathrm{S} / \mathrm{C}$, the lower the fertility rate. The high value of $\mathrm{S} / \mathrm{C}$ is due to the delay of breeders and IB officers in detecting lust as well as inappropriate timing for IB, delays in IB causing pregnancy failure. Jalius (2011) explained that the high and low values of $\mathrm{S} / \mathrm{C}$ were influenced by the accuracy of estrus detection, the timing of $\mathrm{AI}$, and the reproductive condition of female cattle. Ihsan and Wahjuningsih (2011) added that the high S/C value is inseparable from the average nutrition content in the feed which greatly affects the reproductive condition of the female.

\subsubsection{Conception Rate (CR) Value}

Conception rate or conception rate is the main parameter in the assessment of artificial insemination results, namely the percentage of cows that are pregnant at the first insemination (Novita et al., 2019). The conception rate is determined based on the results of the diagnosis through a rectal examination (rectal palpation) by a veterinarian or special officer within 40 to 60 days after pregnancy (Feradis, 2010).

The results of the study can be seen that the success of AI in Padang Pariaman Regency is classified as very good because the average value of $\mathrm{CR}$ is $70.35 \%$. This figure is almost the same as the research of Novita et al. (2019) in Juli District, Bireuen Regency, Aceh Province with a CR rate of $88.63 \%$. This figure is higher than the statement by Hardjopranjoto (1995) that the ideal conception rate for a cattle population is $60-75 \%$, the higher the CR, the more fertile the cows, and vice versa.

Fanani, et al. (2013) stated that the CR value was determined by male fertility, female fertility, and insemination techniques. Male fertility, one of which is the responsibility of the Artificial Insemination Center (BIB) which produces frozen semen in addition to storage management at the inseminator level. Female fertility is the responsibility of the breeder, assisted by a veterinarian in charge of monitoring the health of the mother cow. Meanwhile, the implementation of IB is the responsibility of the inseminator. The conception rate is the percentage of participants who are pregnant (Susilawati, 2011).

Rusumawati and Leondro (2014) that the physiological factors of female cattle also affect the conception rate, namely genetic factors, environmental factors, reproductive anatomy and hormonal conditions, body condition score, and eco parasites and endoparasites. In addition, the value of the conception rate is influenced by several factors including lust returning after giving birth and remarriage after giving birth (Dirgahayu et al., 2015).

\subsubsection{Calving Rate (CVR)}

The birth rate or Calving Rate is a number obtained by representing the number of children born from the result of one marriage (whether in the first marriage, second and so on) (Novita et al., 2019).

The Calving rate from the results of the research in Kabupaten Padang Pariaman is $45.98 \%$. This result is lower than the research of Rosikh, et al. (2015) that the calving rate of Ongole Peranakan cattle in IB in Dukun District, Gresik Regency is $65 \%$. According to Novita et al. (2019) that the value of the calving rate depends on the work efficiency of the inseminator, male fertility, female fertility during insemination, the health of female reproductive organs, and the ability to receive children in the womb until the time of birth. The absolute reproductive value of a female can only be determined after the birth of a live and normal cub.

Yulyanto et al. (2014) added that the most realistic assessment of IB is to calculate the number of offspring if the results of insemination have not produced children standing next to their mothers, then IB cannot be said to be successful. The high number for the Calving Rate is due to the inseminator skills that are already quite good, the ability of farmers to pay attention to their cattle during pregnancy and also the ability of the mother to take care of her child in the womb until the time of birth.

Generally, in the research area, many breeders do not separate their pregnant cattle and keep them in cages with other livestock. The treatment of farmers is also an influence on the birth rate of livestock. Susilo (2005) added that the factors that cause birth failure and can reduce $\mathrm{CR}$ are embryonic death, abortion, and fetal mummification during pregnancy. There were also several cases in the research area regarding the error of officers in giving insemination, namely the seeds given did not match the BCS (Body Condition Score) of the inseminated cows. According to the results of interviews with farmers, there 
was also an error by the officer in giving artificial insemination which turned out to be the acceptor was pregnant, causing the cow to abort or miscarry.

\subsection{Livestock Reproduction Success Rate Based on Cattle Nation}

Different breeds of cattle have different reproductive performances. The success rate of artificial insemination in Padang Pariaman Regency can be distinguished based on the breeds of beef cattle in Padang Pariaman Regency, namely Coastal cattle, Bali cattle, Simental crossbreeds, Brahman cattle, PO cattle, and Limousin crossbreeds (Table 7).

Table 7. Value of Service per Conception $(S / C)$, Conception Rate (CR), and Calving Rate (CVR) of Cattle by Nation in Kabupaten Padang Pariaman.

\begin{tabular}{clccc}
\hline No. & Breed Type & S/C & CR & CVR \\
\hline 1. & Pesisir cow & 1.34 & $72.74 \%$ & $48.46 \%$ \\
2. & Bali Cow & 1.34 & $70.48 \%$ & $40.96 \%$ \\
3. & Simmental & 1.44 & $65.28 \%$ & $45.08 \%$ \\
& Crossbreed Cow & 1.54 & $63.63 \%$ & $63.64 \%$ \\
4. & Brahman Cow & 1.54 & $57.14 \%$ & $40.00 \%$ \\
5. & PO cows & 1.28 & $78.12 \%$ & $37.50 \%$ \\
6. & Limousine & & & \\
& Breed Cow & & &
\end{tabular}

Source: Primary data that has been processed by researchers, 2021.

Based on Table 8, the $\mathrm{S} / \mathrm{C}$ value in Coastal cattle is the same as the $\mathrm{S} / \mathrm{C}$ value in Bali cattle in Padang Pariaman Regency, which is 1.34 times. The $\mathrm{S} / \mathrm{C}$ value of Bali cattle in this area is lower than the study by Nubatonis and Dethan (2021). The S/C value of Limousin crossbreed cattle was the lowest at 1.28 times. This indicates that the fertility of the Limousin cattle is quite good and the S/C value of Brahman cattle is the same as that of PO cattle, which is 1.54 times. This study is following the opinion of Ihsan and Wahjuningsih (2011) which states that Bos taurus (Limousin) cattle have high reproductive characteristics, large body size with medium to high growth rates, while the Bos indicus (PO) cattle have poor characteristics in terms of reproduction and speed of growth, but the nature of breastfeeding to their children (mothering ability) is very good.

The conception rate (pregnancy rate) is taken from the percentage of females who are pregnant in the first artificial insemination. The highest percentage of pregnant cows was Limousin crossbreed cattle, which was $78.12 \%$ and the lowest $\mathrm{CR}$ value was $\mathrm{PO}$ cattle with a percentage of $57.14 \%$. The results of this study are following the research of Wiranto, et al (2020) who researched PO crossbreeds with Limousin crossbreed cattle with CR values of $58.97 \%$ and $74.03 \%$, the conception rate value of Limousin Crossbreed cattle was better than Ongole Crossbreed cattle. . This is because farmers are more intensive in maintenance, especially in feeding.

Calving Rate is the percentage of the number of females that gave birth to live cows from the number of mated acceptors. The highest calving rate in beef cattle in Padang Pariaman Regency is Brahman cattle at $63.64 \%$, while the lowest is Limousin crossbreeds at $37.50 \%$. According to Yulyanto, et al. (2014) the physiological age status of cattle affects the percentage of CVR. Cows that have never given birth will be more sensitive to the risk of birth failure compared to cows that have given birth to calves. Ball and Peters (2004) stated that a large population of fertile cows inseminated with fertile semen could produce a CVR of $62 \%$. The amount of CVR is influenced by the fertility of female cattle and male cattle or male semen. Susilo (2005) added that the factors that cause birth failure and can reduce CVR are embryonic death, abortion, and fetal mummification during pregnancy. CVR also depends on the work efficiency of the inseminator, male and female fertility, and the ability of the mother to raise children from the womb until the time of birth.

\subsection{Implications of Artificial Insemination on farmer's income}

The implications of the results of artificial insemination can be seen based on the results obtained and the costs incurred. From the results of the research, it was found that 45 farmers sold their livestock to 93 farmers who were used as respondents. With 45 artificially inseminated cattle that have been sold in the past year. Can be seen in Table 8 .

Table 8. Beef Cattle Result of Artificial Insemination.

\begin{tabular}{clcc}
\hline No. & \multicolumn{1}{c}{$\begin{array}{c}\text { Types of } \\
\text { livestock } \\
\text { produced by IB }\end{array}$} & Amount & $\%$ \\
\hline 1. & Female & 9 & 20 \\
2. & Male & 36 & 80 \\
\hline & & 45 & $100 \%$ \\
\hline
\end{tabular}

Source: Primary data that has been processed by researchers, 2021.

\subsubsection{Variable Cost}

Variable costs are usually defined as costs whose size is influenced by the production obtained. For example, costs for production facilities, labor needs to be added, fertilizers also need to be added, and so on, so that these 
costs vary depending on the size of the desired production (Soekartawi, 1995). Variable costs can be seen in Table 9.

Table 9. Variable Costs of Beef Cattle Business.

\begin{tabular}{clr}
\hline No. & Variable Cost Component & \multicolumn{1}{c}{ Unit (Rp) } \\
\hline 1. & Feed & 2.379 .096 \\
2. & Drugs & 20.537 \\
3. & Farm labor & 12.000 .000 \\
4. & Artificial Insemination & 77.258 \\
& Services & \\
\hline
\end{tabular}

Total Variable Cost $\quad 14.476 .891$

Source: Primary data that has been processed by researchers, 2021.

The cost component calculated for beef cattle farmers who use AI in the District of Padang Pariaman Regency is feed, where feed is the main support in the production process in addition to genetic and management factors (Parakkasi, 1999). Tumober (2014) also added that the cost of medicines/vaccines is the smallest of the total production costs. Variable costs incurred by farmers.

Table 9 shows the variable cost components for feed amounted to Rp. 14.476.891 from 93 respondents, while the cost of medicines from 45 respondents varies from $\mathrm{Rp}$. 15,000 to Rp. 125,000 with a total cost of Rp. 20.537, which is only issued if the livestock is sick, giving vaccines and giving deworming medicine.

Labor costs amounted to Rp. 12,000,000. For labor, not all breeders use labor. There are only 5 breeders who use labor. Labor costs are calculated per day multiplied by the wages of farmworkers prevailing at the farmer's location. Furthermore, for the cost of artificial insemination services that are given free of charge because the cost of insemination itself is free but the farmers still provide it as a substitute for the transportation costs of officers, from 93 respondents amounting to Rp.14.476.891. artificial insemination amounted to Rp. 77.258.

\subsubsection{Fixed Cost}

Fixed costs are generally defined as costs that are relatively fixed in amount and continue to be incurred even though the product obtained is large or small. The amount of fixed costs does not depend on the size of the production costs obtained. For example, the costs for taxes will still be paid even if the results of the farming are large or fail (Soekartawi, 1995). Fixed costs can be seen in Table 10.
Table 10. Fixed Costs of Beef Cattle Business

\begin{tabular}{llr}
\hline No & Fixed Cost Component & Unit (Rp) \\
\hline 1. & Cowshed & 289.010 \\
2. & Cow barn equipment & 41303 \\
3. & Breeds & 6.519 .354 \\
\hline \multicolumn{2}{l}{ Total Variable Cost } & 6.849 .667 \\
\hline $\begin{array}{l}\text { Source: Primary data that has } \\
\text { researchers, 2021. }\end{array}$ & & processed by
\end{tabular}

In Table 10, the cost components calculated for beef cattle farmers in Kabupaten Padang Pariaman are land rent, cages, and equipment. For land rent, generally, not all breeders rent land. Farmers who live in rural areas own their land and the livestock is only released on plantation land owned by farmers.

For housing depreciation costs around Rp. 125,000 to Rp. $1,000,000$ depending on the construction of the cage made by the breeder, whether the cage is made of wood with a concrete floor or a wooden floor with a dirt floor. As for the equipment for the cages, farmers still use traditional equipment in the form of shovels, hoes, sickles, ropes to tie cattle and sacks. For seedlings amounting to Rp. 6.519.354, from the information, obtained the lowest cost of seeds is Rp. 3,000,000 and the highest 15,000,000.

Joesron and Fathorrozi (2003) stated that the total cost is the sum of total costs and variable costs in the production process. The variable cost of 93 respondents is Rp. 14.476.891 and fixed costs are Rp. 6.849.667 so the total cost is Rp. 21.326.558.

\subsubsection{Reception}

According to Soekartawi (1995), that farm income is the multiplication between the production obtained and the selling price. The revenue obtained is the selling value of the production of beef cattle farmers who use artificial insemination in the Padang Pariaman Regency (Table 11).

Table 11. Results of Analysis of Beef Cattle Business Revenues Using $I B$

\begin{tabular}{clr}
\hline No & \multicolumn{1}{c}{ Reception } & Unit (Rp) \\
\hline 1. & IB Livestock Sales & 10.333 .334 \\
2. & Temporary & 13.638 .709 \\
3. & Livestock & 47.825 \\
& Price/Value IB & \\
& Cattle Manure &
\end{tabular}

\begin{tabular}{l}
\hline \multicolumn{2}{c}{ Total Reception } & 24.019 .868 \\
\hline Source: Primary data that has been processed by \\
researchers, 2021.
\end{tabular}


Based on the results of interviews with farmers for the sale of IB livestock, the price varies depending on the type of livestock sold. There are calves, non-productive or rejected females, and there are also males who are sold for slaughtering sacrificial animals. For the lowest price $(<1$ year) around Rp. 3,000,000 - Rp. 8,000,000 and the highest is for males with sales ranging from $\mathrm{Rp}$. 13,000,000 - Rp. 22,000,000. rejected, sick, and barren female cattle at Rp. 8,000,000 - Rp. 11,000,000. Average sales are for cattle $<1$ year old and heifers.

The added value of livestock that is not sold from the 45 breeders, 48 farmers have not sold their livestock and will continue to increase in value if they continue to be maintained. The temporary livestock value added from this research is Rp. 24.019.868 of the 93 farmers.

\subsubsection{Advantage}

Profit or net income is obtained from the total gross income or revenue minus the total cost of production. The results of the profit analysis can be seen in Table 12 .

Table 12. Results of Profit Analysis of Beef Cattle Breeders from $I B$

\begin{tabular}{clr}
\hline No. & Advantage & Unit (Rp) \\
\hline 1. & Reception & 24.019 .868 \\
2. & Total Cost & 21.326 .558 \\
\hline & Advantage & 2.693 .310
\end{tabular}

Source: Primary data that has been processed by researchers, 2021.

Based on the results of the profit analysis in Table 18, farmers who use artificial insemination benefit from the difference between receipts or sales of IB livestock, sales of livestock manure and the value-added of livestock that is not sold (Rp. 24.019.868), and the total cost (Rp. 21.326.558). The average profit obtained from 93 farmers who have sold their beef cattle in the last 1 year of IB/head cattle in Padang Pariaman Regency is around Rp. 2.693.310/per year farmer who sells of cattle and breeder who has not sold his cattle. Where the average profit of this breeder is higher than the research of Motintja et al. (2015) where the average profit of IB breeders on PO cattle in West Tompaso District is around Rp. $733,475 /$ head.

To see the level of success and efficiency of beef cattle breeders in Padang Pariaman Regency, it is necessary to calculate the Revenu Cost ratio (R/C). If $\mathrm{R} / \mathrm{C}$ $>1$ means that the beef cattle business is feasible to run, while $\mathrm{R} / \mathrm{C}=1$ means that the cattle business has reached the break-even point, which is not making a profit (breakeven revenue). Meanwhile, if the $\mathrm{R} / \mathrm{C}<1$, the beef cattle business is not feasible. Where revenue is revenue divided by cost or production costs, as follows:

$$
\mathrm{R} / \mathrm{C}=\frac{\mathrm{Rp} \cdot 24 \cdot 019 \cdot 868}{\mathrm{Rp} \cdot 21 \cdot 326 \cdot 558}=1,12
$$

From these results, the $\mathrm{R} / \mathrm{C}>1$ means that the business is profitable and feasible to run. According to Sugiarti and Siregar (1998), AI treatment that has been carried out on cattle can have an impact on the income of farmers. With artificial insemination, it will increase the diversity of livestock and add superior seeds to livestock so that the selling value of livestock becomes higher. And with the presence of artificial insemination, can save farmers in the maintenance of males.

\section{CONCLUSION}

Based on the results of research on the success rate of Artificial Insemination in Beef Cattle in Padang Pariaman Regency has been running very well, it can be concluded:

1. Service per Conception (S/C) 1.36 times, Conception Rate (CR) 70.32\%, and Calving Rate (CVR) $45.98 \%$.

2. The highest $\mathrm{S} / \mathrm{C}$ value was in Brahman and PO cattle as much as 1.54 times and the lowest was in Limousin crossbreed cattle as much as 1.28 times. The highest $\mathrm{CR}$ value was in Limousin breeds of $78.12 \%$ and the lowest was in PO cattle of $57.14 \%$. The highest CVR value was in Brahman cattle at $63.64 \%$ and the lowest was in Limousin crossbreeds at $37.50 \%$.

3. The economic value or implication of artificial insemination is based on the pregnancy and the birth of the livestock and the profits obtained from the cattle that are born so that there is an added value and reduced by the cost of feed, cage equipment, drug costs affect the income of farmers so that the net profit obtained by the breeder. The average income of 1 farmer who performs artificial insemination is Rp.2.693.310 per year.

\section{REFERENCES}

[1] Adrial. 2010. Potensi Sapi Pesisir dan Upaya Pengembangannya di Sumatera Barat. Jurnal. Penelitian dan Pengembangan Pertanian 29(2): 66-72

[2] Badan Pusat Statistik Kabupaten Padang Pariaman. 2020. Jumlah Kelahiran Ternak Sapi Per Ekor Per Kecamatan Tahun 2018-2021. https://padangpariamankab. bps.go.id/indicator/24/149/1/jumlah-populasi-sapi-menurutjumlah-per-kecamatan.html. Diakses pada tanggal 26 Januari 2020.

[3] Dirgayahu, F. F., M. Hartono, P.E. Santosa. 2015. Conception Rate pada Sapi Potong di Kecamatan Jati Agung 
Kabupaten Lampung Selatan. Jurnal Ilmiah Peternakan Terpadu. Vol. 3 (1): 7-14.

[4] Fanani, S., Subagyo, Y. B. P dan Lutojo. 2013. Kinerja Reproduksi Sapi Perah Peranakan Friesian Holstein (PFH) di Kecamatan Pudak, Kabupaten Ponorogo. Tropical Animal Husbandry. Vol. 2 (1):21-27.

[5] Feradis. 2010. Reproduksi Ternak. CV. ALTABETA. Bandung.

[6] Hafez, E. S. E. 1993. Artificial insemination. In:HAFEZ, E.S.E. 1993. Reproduction inFarm Animals.

[7] Hendri, Z. Udin dan Jaswandi. 2004. Mata Kuliah Bioteknologi Reproduksi Ternak. Unand, Padang.

[8] Ichsan, Amirul. 2020. Penampilan Sifat Kualitatif dan Reproduksi Sapi Betina F1 Persilangan Sapi dan Sapi Pesisir di Kabupaten Padang Pariaman. Pascasarjana Universitas Andalas. Padang.

[9] Ihsan, M.N dan S. Wahjuningsih. 2011. Penampilan Reproduksi Sapi Potong di Kabupaten Bojonegoro. Jurnal Ternak Tropika. Vol 12(2) : 76-80

[10] Iswoyo dan P. Widyaningrum. 2008. Performans Reproduksi Sapi Peranakan Simmental (Psm) Hasil Inseminasi Buatan di Kabupaten Sukoharjo, Jawa Tengah. Jurnal Ilmiah Ilmu-ilmu Peternakan. 11(3): 125-133.

[11] Jalius. 2011. Hubungan Mortalitas Progresif dan Keutuhan Membran Sperma Dalam Semen Beku Sapi Bali Dengan Keberhasilan Inseminasi. Laboratorium Reproduksi Ternak Fakultas Peternakan Universitas Jambi. Jambi.

[12] Kusumawati, E.D dan H. Leondro. 2014. Inseminasi Buatan. Unikama, Malang.

[13] Luthfi, M., Anggraeny, Y.N., dan Purwanto. 2011. Perbedaan Performan Reproduksi Sapi PO dan Brahman Cross di Berbagai Lokasi di Jawa Tengah dan Jawa Timur. Seminar Nasional Teknologi Peternakan dan Veteriner Loka Penelitian Sapi Potong. Grati Pasuruan.

[14] Monintja, M.Y., F.S. Oley, B.F. Sondakh dan F.N.S. Oroh. 2015. Analisis Keuntungan Peternak Sapi Peranakan Ongole (PO) Yang Menggunakan Inseminasi Buatan (IB) di Kecamatan Tompaso Barat. Jurnal Zootek Vo.35 No.2: 201209.

[15] Nuryadi dan S. Wahyuningsih. 2011. Penampilan Reproduksi Sapi Peranakan Ongole dan Sapi Peranakan Limousin di Kabupaten Malang. Jurnal Ternak Tropika. Vol 12(1) : 76-81.

[16] Novita, C. I., M. A. N. Abdullah, E.M. Sari, dan Zulfian. Evaluasi Program Inseminasi Buatan Pada Sapi Lokal Betina di Kecamatan Juli, Kabupaten Bireuen, Provinsi Aceh. Fakultas Pertanian Universitas Syah Kuala, Aceh. Jurnal Agripet Vol. 19.

[17] Parakkasi, A. 1999. Ilmu Nutrisi dan Makanan Ternak Ruminan. Universitas Indonesia. UI Press. Jakarta.

[18] Riyanto, J., Lutojo., Barcelona., D.M. 2015. Kinerja Reprodukti Induk Sapi Potong pada Usaha Peternakan Rakyat di Kecamatan Mojogedang. Jurnal Sains Peternakan. 3(2) : 73-39.

[19] Rusdi, B., Hartono, M., Suharyati, S., 2016. Calving Interval pada Sapi Bali di Kabupaten Pringsewu. Jurnal Ilmiah Peternakan Terpadu. Vol.4(4) : 277-283.
[20] Rosikh A, Aria AH, Qomaruddin M. 2015. Analisis perbandingan angka calving rate sapi potong antara kawin alami dengan inseminasi buatan di kecamatan dukun kabupaten gresik. Jurnal Ternak Vol.6(1):13-17.

[21] Soekartawi. 1995. Analisis Usaha Tani. Universitas Indonesia Press, Jakarta.

[22] Sudarmono, A. S. dan Sugeng Y. B.2016. Panduan Beternak Sapi Potong. Penebar Swadaya. Jakarta.

[23] Sugiyono. 2005. Metode Penelitian Kualitatif. Alfabeta, Bandung.

[24] Susilawati, T. dan Affandy, L. 2004. Tantangan dan Peluang Peningkatan Produktivitas Sapi Potong Melalui Teknologi Reproduksi Tantangan dan Peluang Peningkatan Produktivitas Sapi Potong Melalui Teknologi.

[25] Susilawati, T. 2011. Tingkat keberhasilan inseminasi buatan dengan kualitas dan deposisi semen yang berbeda pada sapi peranakan ongole. Ternak Tropika. Vol. 12 (2):15-24.

[26] Susilo, T. 2005. Efisiensi Produksi Program Inseminasi Buatan Terhadap Sapi Lokal Pada Daerah Lahan Basah dan Kering di Kabupaten Magelang, Provinsi Jawa Tengah. Tesis Master. Universitas Diponegoro, Semarang.

[27] Talib C, Inounu I, Bamualim A. 2007. Restrukturisasi Peternakan di Indonesia. Analisis Kebijakan Pertanian.1(5): $1-14$.

[28] Tumober, J. 2014. Analisis Keuntungan Pemeliharaan Sapi di Kecamatan Suluun Tareran Kabupaten Minahasa Selatan. Jurnal Zootek Vol 24 No.2 : 18-26.

[29] Udin, Z. 2012. Teknologi Inseminasi Buatan dan Transfer Embrio Pada Sapi. Penerbit Sukabina Press, Padang

[30] Yulyanto, C. A., T. Susilawati dan M. N. Ihsan. 2014. Penampilan reproduksi sapi peternakan onggol (PO) dan sapi peranakan limousin di Kecamatan Sawo Kabupaten Ponorogo dan Kecamatan Tugu Kabupaten Trenggalek. Jurnal Ilmu-Ilmu Peternakan. Vol. 24 (2):49-57. 